\title{
On a new tapeworm, Circumoncobothrium govindii of fresh water fish Channa marulius from Godavari basin India
}

Fartade AM and R.S. Chati

Department of Zoology, Shri Shivaji Mahavidyalaya, Shivaji Nagar, Barshi, 413411 India

\section{ABSTRACT}

The present communication deals with the description of a new species of genus Circumoncobothrium govindii Sp. Nov., from fresh water fish Channa marulius from Godavari basin provided new data on their morphology. The present worm differ from the known species of the genus in the shape and size of the scolex, number of hooks and arrangement of rostellum, shape of segment, number of testes, position of cirrus pouch and arrangement of vitellaria.

KEY WORDS: CIRCUMONCOBOTHRIUM GOVINDII, CHANNA MARULIUS, GODAVARI BASIN

\section{INTRODUCTION}

The genus Circumoncobothrium was erected by Shinde (1968) from the intestine of fresh water fish Ophiocephalu sleucopunctatus as a type species C. ophiocephali Jadhav and Shinde, (1976) added three new species of this genus viz., C. aurangabadensis and $C$. raoiifrom Mastacembelus armatus and C. gachuai from Ophiocephalus gachua. Chincholikar and Shinde, (1976) described two new species of this genus C. shindei from fresh water fish Mastacembelus armatus and C. bagariusi from Bagarius species. Shinde, (1977) reported C. khami from Ophiocephalusstriatus. Jadhav et.al, (1990) described C. yamaguti, from Mastacembelus armatus Shinde et.al. (1994) reported C. alii from Mastacembelus armatus.Patil et al, (1998) added C. vadgaonensis as a new species to this genus from Mastacembelus armatus. Wongasawad and Jadhav, 1998 added C. baimaii from Mastacembelus armatus.C. punctatusi was added by Kalse and Shinde, 1999 from Ophiocephalus punctatus. Shinde et. al., 2002 described C. mastacembalusae as a new species from Mastacembelu sarmatus.Pawaret. al., 2002 reported C. armatusae (minor)) from Mastacembelu sarmatus to this genus. Tat and Jadhav, 2004 reported C. manjari from Ophiocephalus gachua. Supugade et. al., 2005 added C.vitellariensisfrom Mastacembelus arma-

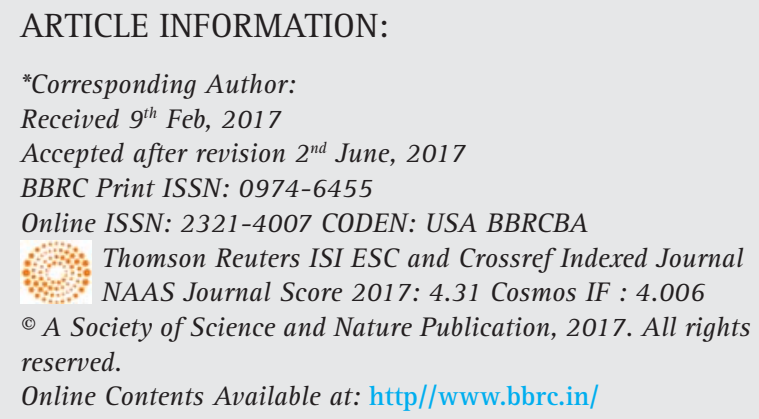


tus. Kharade et al., 2007 added C. cirrihinae from Cirrihinamrigala. Shelke et al., 2007 added C. mehdii from Mastacembelusarmatus. Pardeshi et al., 2007 added C. ambajogaiensis from Mastacembelus armatus.Jawalikar et al., 2008 added C. yogeshwari from Mastacembelus armatus. Borde and Sushil Jawale, 2008 added C. purnae from Mastacembelus armatus. Kalse et al., 2009 added C. naidui from Mastacembelus armatus. Shah, 2010 added C. paaddeithenensis from Mastacembelus armatus. Menkudale and Jawale, 2010 added C. thapari from Ophiocephalus stratus. Pardeshi and Hiware, 2011 added C. jadhavae from Mastacembelus armatus. Lastly Dhole and Kadam, 2011 added C. clariase from Clariasbatrachus.

\section{MATERIAL AND METHODS}

The present specimens were recorded from the intestine of the freshly killed fresh water fish Channa marulius (Hamilton 1822) from Godavari Basin during the period of June 2009-May 2011. Each fish was dissected and examined in all parts like fins, gills, scales, and visceral organs under a microscope. Fishes were opened up dorso-ventrally and the internal organs examined. The entire digestive system was removed and placed in a Petri dish with physiological saline. Infection of each group of parasites was treated as follows: collected parasites were first relaxed and then fixed in hot 4\% formalin and stain using Harris haematoxyline. Stained parasites were washed in distilled water, dehydrated in ascending grades ofalcohol, cleared in xylene, mounted in D.P.X. Drawings were made using a camera lucida. Identification was carried out by using system Helminthum vol. II, (Yamaguti, 1956)

Eight mature specimens were collected from the intestine of fresh water fish Channamarulius (Hamilton 1822) from Paithan Dist- Aurangabad in the month of March 2010.The parasite were flattened, preserved in 4\% formalin, stained with Harris haematoxylin, passed through various alcoholic grades, cleared in xylene, mounted in D.P.X. Whole mount slides were prepared for further anatomical studies. Drawing was made with the aid of Camera Lucida. All measurements are given in millimeters. All the cestodes are long, consisting of scolex, immature, mature and gravid proglottids. The scolex large well developed conical in shape which measures 7.15(7.05-7.24) in length and 4.06(3.54-4.57) in breadth, the anterior end of the scolex terminates in a rostellum; the rosetellum is armed with 58-60 hooks and arranged in semicircle. The scolex bears two large bothria, which are extended anterior to posterior end, posteriorly it is globular and measures 4.53(4.45-4.62) in length and 0.90(0.82-0.99) in breadth.
Neck is present but short measures 1.62(1.33-1.90) in length and 2.80(2.74-2.86) in breadth. Mature segment small, rectangular broader than long measures 0.74(0.69$0.79)$ in length and 2.88(2.70-3.06) in breadth. The testes oval to rounded 50-59 in numbers, measures 0.04(0.030.06) in length, and 0.02(0.016-0.024) in breadth, spread in the segment.The cirrus pouch is oval, medium in size, anterior to ovary and measures $0.049(0.033-0.066)$ in length, and 0.14 in breadth. The cirrus is thin tube measures 0.264 (0.23-0.29) in length and 0.02(0.016-0.024) in breadth.Ovary is irregularly bilobed with long isthmus, each lobe is different in shape, large measures 1.22(1.181.25) in length and 0.099(0.066-0.13) in breadth situated in the middle of the segment. The vagina is thin coiled tube, starts from genital pore, posterior to cirrus pouch and measures 0.115(0.099-0.132) in length and 0.04 in breadth. Genital pore small, rounded and measures 0.06 in length and breadth.The gravid segment are small, rectangular filled with uterus. The uterus is saccular, filled with numerous egg and measures 0.18(0.11-0.25) in length and $0.40(0.31-0.45)$ in breadth. The eggs are oval in shape.The vitellaria are granular and arranged in two rows at each side of the segment.

The genus Circumoncobothrium was established by Shinde in 1968 as a type species C. ophiocephali from Ophiocephalus leucopunctatus. The present worm comes closer to all the known species of the genus Circumoncobothrium Shinde, 1968 in general topography of organs. But differs due to some characters from followingspecies. The present cestode differs from C. ophiocephaliShinde,(1968) in having distinct scolex, broad in the middle and tapering at both the ends, rostellar hooks 80 in numbers, presence of neck, ovary compact, single conical mass, vitellaria follicular and reported from Ophiocephalus leucopunctatus, in India.

The present worm differs from C. aurangabadensisJadhav and Shinde,(1976) in having the scolex broad in the middle and narrow at both the ends, hooks 42 in numbers, presence of neck and testes 135-145 in numbers. The present tapeworm differs from C. raoii Jadhav and Shinde,(1976) in having scolex broad in the middle and narrow at both the ends, hooks 46 in numbers, arranged in single circle, neck present,testes 210-215 in numbers.

The present parasite differs from C. gachua Jadhav and Shinde,(1976) in having the scolex pear shaped, hooks 46 in numbers, neck present, mature proglottid squarish, testes 375-400 in numbers, vitellaria follicular, arranged in two rows and reported from Ophiocephalus gachua, in India. The present tapeworm distinguish from C. shinde Chincholikar and Shinde,(1976) in having the scolex narrow anteriorly and broad posteriorly, hooks 49 in numbers, neck present, testes $260-275$ in numbers, evenly distributed and ovary dumb-bell shaped. 
The present worm differs from C. bagariusi Chincholikar and Shinde,(1976) in having the scolex narrow anteriorly and broad posteriorly, hooks 55 in numbers, testes 275-285 in numbers, arranged in two lateral fields, vitellaria follicular and reported from Bagarius sp., in India. The present parasite differs from C. khami Shinde, (1977) in having the scolex cylindrical, hooks 48 in numbers, lancet shaped, mature proglottidssquarish, testes 190200 in numbers, evenly distributed, vitellaria follicular and reported from Ophiocephalus sp.,in India.The present cestode differs from C. yamaguti Jadhav et.al, (1990) in having the scolex distinct, narrow anteriorly and broad posteriorly and testes $130-150$ in numbers.

The present worm differs from C. alii Shinde et. al., (1994) in having scolex triangular, hooks 34 in numbers, neck present and testes 230-240 in numbers. The present tapeworm differs from C. vadgaonensis Patil et.al., (1998) in having the scolex triangular, hooks 56 in numbers, neck present, testes 490-510 in numbers and vitellaria follicular. The present cestode differs from $C$. baimaii Wongsawad and Jadhav, (1998) in having the scolex pear shaped, hooks 48 in numbers, neck present, testes 88-100 in numbers, ovary compact and reported from Masta cembelusarmatus in Chang Mai.

The present worm differs from C. punctatusi Kalse and Shinde,(1999) in having scolex rectangular, hooks 40-50 in numbers, neck present, mature proglottids squarish, testes 140-150 in numbers, vitellaria follicular, arranged in 3-6 rows and reported from Ophiocephalus punctatus, in India. The present worm differs from C. armatusae Shinde et. al., (1999) in having scolex triangular, hooks 58 in numbers, neck present, testes $90-100$ in numbers, ovary compact and vitellaria follicular, arranged in 3-4 rows on lateral side of the segments. The present parasite differs from C. mastacembelusae Shinde et. al., (2002) in having scolex pear shaped hooks 30 in numbers, testes 130-140 in numbers, ovary compact and vitellaria follicular, arranged in 2-3 rows on each lateral side. The present cestode differs from C.armatusae (minor) Pawar et. al., (2002) in having scolex triangular, hooks 58 in numbers, testes 190-200 in numbers and vitellaria follicular. The present form differs from C. manjari Tat and Jadhav,(2004) in having the scolex triangular, hooks 48 in numbers, in single circle, neck present, testes 128145 in numbers, vitellaria follicular and reported from Ophiocephalusgachua, in India.

The present parasite differs from C. vitellariensis Supugade et. al., (2005) in having scolex large, triangular, hook 48 in numbers, testes $250-260$ in numbers and vitellaria follicular, arranged in 3-4 rows.The present parasite differs from $C$. cirrhinae Kharade et al., (2007) in having scolex large, cylindrical, barrel shaped, hooks 56, rostellar, neck short, testes 300-305, medium, oval, ovary dumbbell shaped, medium. The present para- site differs from C. mehdii Shelke et al.( 2007) in having hooks 56 arranged in single circle, neck short, squarish, mature segment medium, squarish, testes 280-290 medium, ovary large, distinctly bilobed, vitellaria follicular, 3-4 rows. The present cestode differs from $C$. ambajogaiensis Pardeshi et al., (2007) in having hooks 18-20 in numbers, neck absent, mature segment ten time broader than long, testes 250-300 in numbers, ovary bilobed, dumbbell shaped, vitellaria follicular. The present worm differs from C.yogeshwari Jawalikar et al., (2008) in having hooks 53 in numbers, neck very short, testes 95-98 in numbers, vitellaria follicular, arranged in two rows. The present worm differs from C. purnae, Borde and Jawale, (2008) in having hooks 52 in numbers, neck absent, mature segment squarish, slightly broader than long, testes 230-235 in numbers, ovary bilobed and vitellaria follicular, arranged in 3-4 rows.

The present parasite differs from C. naidui Kalse et al., (2009) in having scolex cylindrical, hooks 40 in numbers, neck absent, testes 200-210 in numbers, medium rounded, ovary oval, single mass, compact, transversely elongated with acini.The present cestode differs from C. paithenensis Shah, (2010) in having scolex triangular, cylindrical, hooks 58, single circle in four quadrant, neck very short, mature segment two time broader than long, testes 70-80, oval, and vitellaria follicular in two rows.The present form differs from $C$. thapari Menkudale and Jawale (2010) in having host Ophiocephalus stratus, hooks 52 in numbers, neck absent, testes 95 in numbers, medium, oval, ovary medium, lobed, vitellaria follicular 2-3 rows.The present parasite differs from C. jadhavae Pardeshi and Hiware, (2011) in having scolex triangular, dome shaped, hook 35-45 in numbers, neck present, mature segment broader than long, testes 95-105 oval to round, ovary bilobed, vitellaria follicular, arranged in 2 rows.The present worm differs from C.clariasiK.N Kadam and Jaywant Dhole (2011), having scolex triangular, hooks 48 in numbers, testes oval in shape 249259 in numbers, vitellaria follicular arranged 2-3 rows. Reported from Clariasbatrachus in India.

Key to the species of the genus Circumoncobothrium (Shinde, 1968)

$\begin{array}{lll}\text { Neck present } & - & 1 \\ \text { Neck absent } & - & 2 \\ \text { 1) Vitellaria granular } & - & 3 \\ \text { Vitellaria follicular } & - & 4 \\ \text { 2) Mature segment squarish - } & 5 \\ \text { Mature segment broader } & - & 6 \\ \text { than long } & & \\ \text { 3) Scolex conical } & - & \text { C. govindiiSp.Nov } \\ \text { Scolex triangular } & - & \text { C. alli, Shinde et. al. } \\ \text { Scolex pear shaped } & - & \text { C. baimaii, Wongaswad } \\ & & \text { et. al. 1988 }\end{array}$




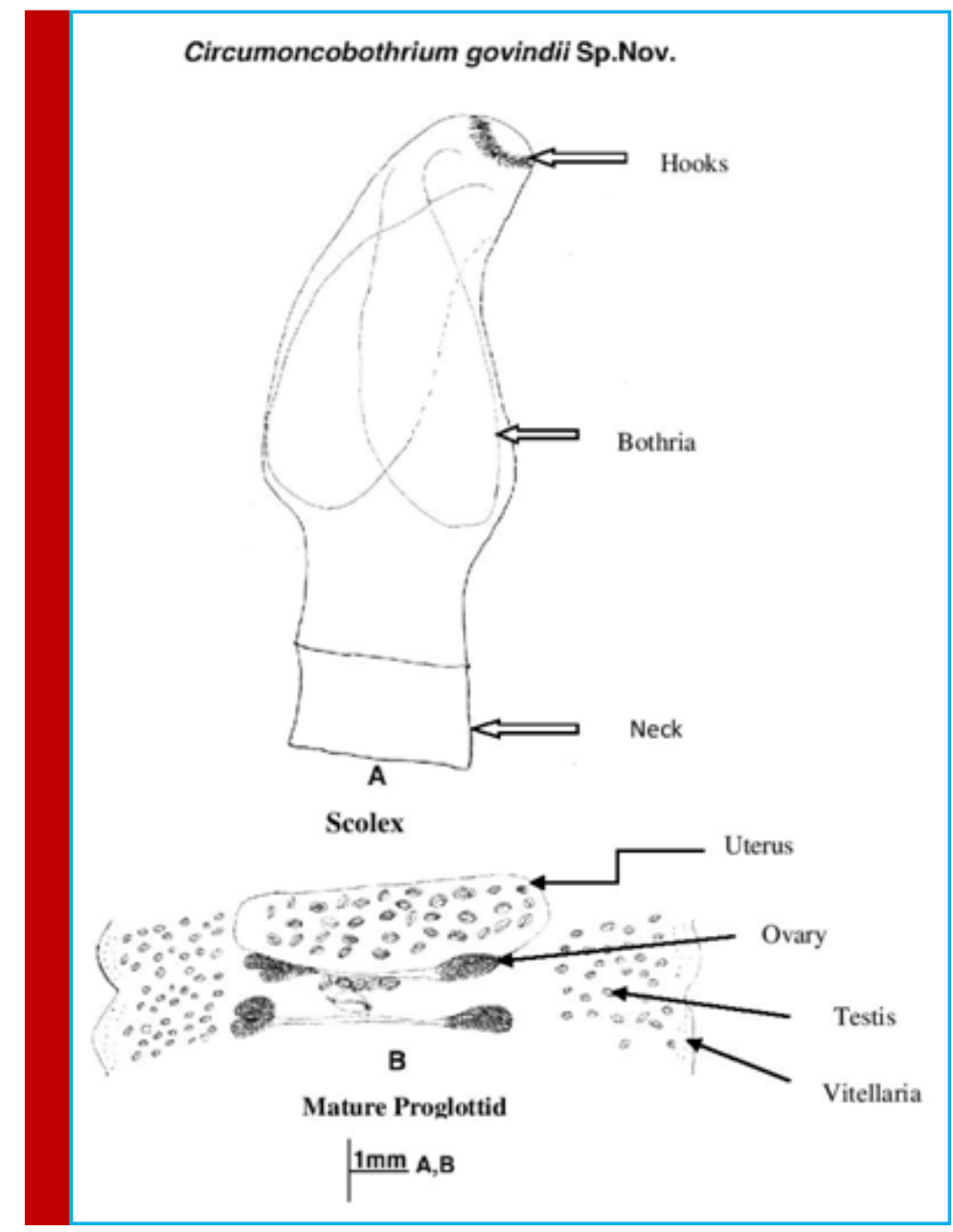

Scolex narrow anteriorly broad Posteriorly

Scolex broad in the middle narrow at both end Scolex cylindrical

4) Mature proglottids squarish

Mature proglottids broader than long 5) Testes $150-200$ in numbers

Testes above 200 in numbers

6) Hooks below 30

Hooks in between 30-40

Hooks in between 40-50

Hooks above 50 in number -

7) Testes below 200
C. Shindeii, Shinde et. al. Testes above 200 in number 1977

7

C. cirrihinae, Kharade et. al. 2007 8

9

C. khami, Shinde, et. al 1968

C. purnae, Borde and Jawale 2008

C. ambajogainsis,

Pardeshi 2011

C. mastacembelusae, Shinde 2002

10

11

C. aurangabadensis, Jadhav. et.al 1976 in number
8) Scolex rectangular in shape -

$\begin{array}{llll} & - & \text { C. gachuaiJadhav } 1980\end{array}$

Scolex triangular $\quad-\quad$ C. mehdii, Shelke 2007

9) Hooks 20-30 in numbers - $\quad$ C. armatusae, Shinde 1999

Hooks 30-50 in numbers - $\quad 12$

Hooks 50-60 in numbers - $\quad 13$

Hooks 60-70 in numbers - 14

Hooks 80 in numbers - $\quad$ C. ophiocephali, Shinde, et.al 1968

10) Scolex triangular $\quad-\quad$ C. vitellariansis, Supugade, 2005

Scolex cylindrical $\quad$ - $\quad$ C. naidui, Kalse et. al. 2009

11) Testes in between $90-100-$

Testes in between 100-150 -

Testes in between 150-200 -
C. thapari, Menkudale, 2010

C. yamaguti, Jadhav. 1990

C. armatusae, Pawar 2002 
Testes above 200 in numbers -

C. bagariusi, Chincholikar, 1997

12) Testes in between 90-110 -

Testes in between 125-150 Testes in between 250-260 13) Testes in between 70-80 -

Testes in between 90-100 -

Testes in between 490-510 2011 2010

C. yogeshwari, Jawalikar 2008.
C. jadhavae, Pardeshi,

C. Manjari, Tat, 2004

C. clariasi, Kadam 2011

C. paithenesis, Shah C. vadgaonensis, Patil 1998

\section{REFERENCES}

Borde, S. N. and S. Jawale. (2008): A new species of Ptychobothridae from a fresh water fish in Marathwadaregion (M.S.). National Journal of Life Sciences. 5 (3):121-124.

Chincholikar, L. N. and G. B. Shinde. (1977): On a new species of Circumonco bothrium Shinde, 1968 (Cestoda:Pseudophyllidea, Carus, 1863) from a freshwater fish in India. Marath. Univ. J. Sci., XVI (Sci. No. 9): 183-185.

Jadhav B. V. and G. B. Shinde. (1976): New species of genus Circumonco bothrium Shinde, 1968 (Cestoda:Pseudophyllidea, Carus, 1863) from a freshwater fish Aurangabad, India.

Jour. of Indian Bio. Asso. 2: 163 - 166.

Jadhav, B. V. (1990): On new pseudophyllidae cestodes from Mastacembelus armatus of Daryapur (M.S.) India.Rivista di Parasitol 7, 19-22

Jawalikar, J. D. S. B. Pawar and G. B. Shinde. (2008): A new cestode Circumoncobothrium yogeshwari n. sp. (Cotyloda: Ptychobothridae) from Mastacembelus armatus. Uttar Prad. Journal. of Zoology 28 (3): 399 - 401.

Kharade, S. V. Yasmin Mulla and G. B. Shinde. (2007): A new cestode Circumoncobthrium cirrhinaen. sp. Cotilodaptycobothridae from cirrhina mrigala. Nat.J.Lif. sci.4 (3) 103-106.

Pardeshi, P. R. and C. J. Hiware. (2011): A new tapeworm Circumoncobothrium jadhavae n.sp. from Mastacembelus armatus(Lecepede) 1800, at Aurangabad M.S. India.recent research in science and technology 3(3): 20-25

Patil, S. R., G. B. Shinde, and B. V. Jadhav. (1998): A new species of the genus Circumoncobothrium Shinde, 1968 (Cestoda: Pseudophyllidae) Carus, 1863 from
Mastacembelus armatus at Vadgaon, (M.S.) India.J.para Dis 1998, 22(2):148-151.

Pawar, S. B. (2002): A new species Circumoncobothrium armatusae n.sp. (Cestoda: Pseudophyllidae) from Mastacembelus armatus at Paithan, India. Riv. Di. Parasit. Vol. XX (LXIII) No.3: 219-222.

Shah, Shabbir Ahmed Yasin. (2010): Taxonomic observations of Circumoncobothrium paithenensis $n$. sp from freshwater fish Mastacembelus armats International Journal of Systems Biology, Volume 2, Issue 2, 2010, pp-21-24.

Shelke, V. P. (2007): A new ptychobothridae tapeworm from Mastacembellus armatus at Aurangabad (M.S.) Nat.J.Lif. sci.4 (3) (72-74)

Shinde, G. B. (1977): On a new species of Circumonco bothrium Shinde, 1968 (Cestoda: Pseudophyllideacarus, 1863) from fresh water fish, M.S.Ibid., XVI: 129-133.

Shinde, G. B., Sarwade, D. V., Jadhav, B. V. and M. A.Mahagan. (1994): On a new species of the genus Circumonco bothrium Shinde, 1968 (Cestoda:Pseudophyllidae) Carus, 1863 from Mastacembelus armatus (Cuv. and Val.) from freshwater fish at Aurangabad (M.S.) India. Rivista Di Parasitologia11 (55):167169.

Shinde, G. B. and A. T. Kalse. (1999): Two new species of genus Circumonco bothrium Shinde, 1968 (Cestoda:Pseudophylidea Carus, 1863) from a freshwater fish at Khandesh (M.S.). Rivita Di. Parasitol., XVI (LX) N.3: 195-198.

Shinde, G. B., Pawar, S. B. and S. P. Chauhan. (2002): A new species Circumonco bothrium mastacembellusae n.sp. (Cestoda: Pseudophyllidae) from Mastacembelus armatus at Paithan, India. Riv. Di. Parasit., Vol. XX (LXII)No. 3: 195-198.

Supugade, (2005): Circumonco bothrium vitellariensis n.sp. Ptycobothriidae (Luhe, 1920) from Mastacembelus armatus (M.S.), India. Trajectory, Vol. 13 No. 1: 43-49.

Tat, M. B. and B. V. Jadhav. (2004): A new species of the genus Circumonco bothrium Shinde, 1968 (Cestoda: Pseudophyllidea) Carus, 1863 from Ophiocephalus gachua at Dhanegaon District, Beed. Nat. Jour. of LifeSciences. 1 (1): 129-132.

Wongsawad, C. and B. V. Jadhav. (1998): Circumonco bothrium baimaii n.sp. (Cestoda: Pseudophyllidae) from fresh water fish, Maesa stream Chiang Mai, Thailand. Rivista Di Parasitologia. Vol. XV(LIX)No.3:291-294 